\title{
Spatial Analysis of Climate Change Effects on Urbanized Delta Territories as a Tool for Planning: The Case of the Lower Parana Delta
}

\author{
Veronica M.E. Zagare, Delft University of Technology (TUDelft), \\ Argentina
}

\begin{abstract}
This paper presents the spatial implication of climate change-related variables and the role of the representation and analysis of the data as a tool for the development of planning policies in urbanized deltas. The presentation illustrates some partial and preliminary results of a broader investigation regarding socio-economic variables too, in order to analyze the spatial impact of changes in deltaic systems. In the deltas' territories, a complex relation between urban patterns and the natural environment takes place. In order to reach successful adaptation policies regarding climate change and urban growth, it is necessary to implement new methodologies to take into account the spatial impacts of each driver and prepare for possible future scenarios. The study is based on the territory of the Lower Parana Delta and the coast of Buenos Aires province, which are complex lands that are very vulnerable to extreme climate events. Specifically, the case study is the coastal Municipality of Tigre, which is being rapidly transformed by natural and urban drivers and suffers the pressures of the demographic growth of Buenos Aires's Metropolitan Area and the deep consequences of climate events.
\end{abstract}

Keywords: Climate Change Effects, Spatial Implications, Urbanized Deltas, Planning Policies, Urban Planning and Design

\section{Introduction}

A

DAPTATION STRATEGIES HAVE become an important focus for research on climate change. They have to deal with global and regional climatic events and also with the specific vulnerabilities of the societies and their capacity to cope with a changing context (Holl and Mauser, 2008). It is important for urban planners and decision makers to identify the spatial implications of those changes in each scale of action, in order to be aware of the possible risks and develop coherent adaptation responses. In this paper, a methodological approach will be presented to understand climate change impacts and their relation with the territory according to its specificities.

The focus on spatial implications is an innovative strategy (Centre for Urban \& Regional Ecology, 2003) to provide stakeholders with a guide to the most concerning issues and their possible future connotations.

This document is structured in three sections and a conclusion. In Section I, an overview of the case study will be presented in order to understand the relevance of the area and the role that it plays for the South American environment. In Section II, the methodological approach will be addressed in order to set the basis for the study, which will be developed

The International Journal of Climate Change: Impacts and Responses C $O M M O N$ Volume 3, Issue 4, 2012, http://www.Climate-Journal.com, ISSN 1835-7156 (C) Common Ground, Veronica M.E. Zagare, All Rights Reserved, Permissions: cg-support@commongroundpublishing.com 
in Section III. Finally, a set of conclusions will be briefly explained, together with a balance of the contribution of the research to the academic and practical fields.

\section{Section I: Overview of the Case Study}

Deltas are complex territories where the coexistence of natural environment, urban dynamics, and climate changes take place. Even though South America has a vast surface full of great biodiversity and natural resources, it presents one of the highest levels of social inequality of the world. $80 \%$ of the inhabitants live in urban areas and the population is expected to grow by $150 \%$ in the next 30 years (London School of Economics and Political Science, 2010). Three quarters of this population live near coastal areas, which are territories naturally sensitive to climate events, so the result is a high natural and social vulnerability (Magrin et al., 2007). The case study is representative of the South American scenario and it is relevant for the hydrology of the region. The Parana River is the third largest river of the American continent, after the Mississippi and the Amazon and it is the most important river of the La Plata Basin, which covers over 3 million $\mathrm{km}^{2}$ distributed in 5 countries: Brazil, Argentina, Bolivia, Uruguay and Paraguay (Figure 1). The river drains to the Atlantic Ocean through the Rio de la Plata, the widest estuary of the world (230 km wide). The Parana Delta is a wetland strategically located close to the most important conurbation of the country, Buenos Aires Metropolitan Area, which has a population of more than 12 million inhabitants (Figure 2). High sedimentation rates make it a very changing territory which front is advancing rapidly being expected to reach Buenos Aires City's coast in about 110 years (Pittau et al., 2004). A multiplicity of jurisdictional authorities, competences and boundaries divides the delta in 18 local governments (Municipalities or Departments) and 3 subnational jurisdictions (3 Pro-vinces). The diversity of functional authorities with huge territorial reach, complex institutional arrangements and conflicting visions on the area's role, converge in making the design and implementation of policies and measures, including water management and land use strategies, inadequate, fragmentary and unsuccessful. Due to that, for the purposes of this study, a representative area was chosen to be analysed according to the problem of climate change and urban growth. The area is the Municipality of Tigre, located in the lower section of the Delta, with around 380.709 inhabitants (INDEC, 2010). Its territory is constituted of islands and continental lands and suffers the pressures of metropolitan urban growth and climate changes. 


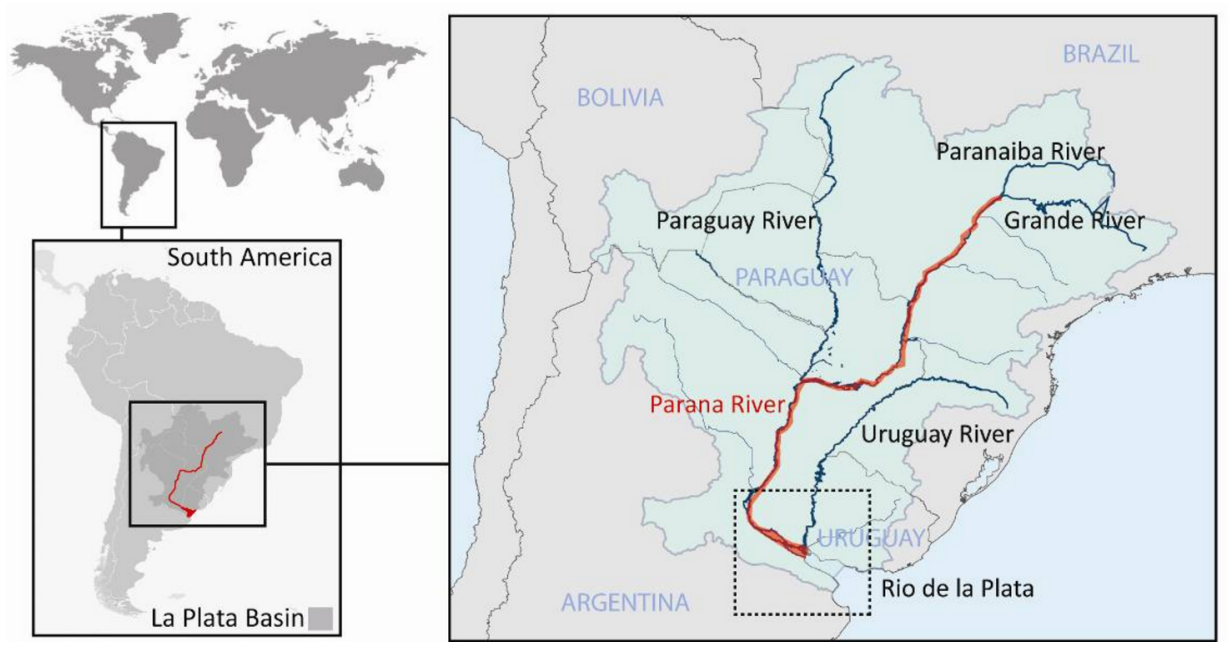

Figure 1: Location of Lower Parana Delta

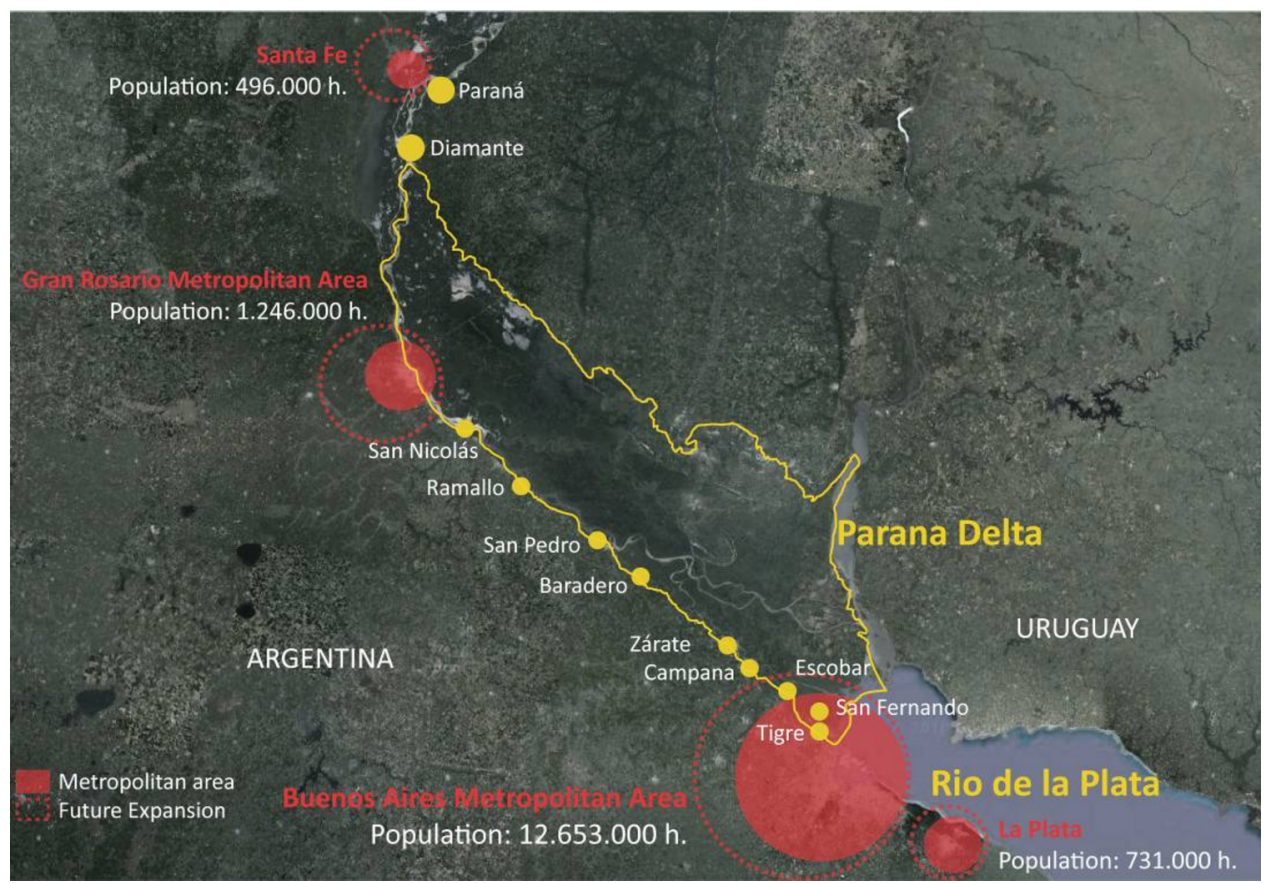

Figure 2: Metropolitan Dynamics in Parana Delta 


\section{Section II: Methodology}

Spatial implication perspective is an innovative way to study climate changes and their relation with the territory. The methodology used in this paper is based on the model developed by the University of Manchester for the study of climate change in North West England (Centre for Urban \& Regional Ecology, 2003). This method consists of the identification of linkages between climate scenarios and socio economic contexts at different scales, based on land use impacts, spatial developments and planning. Due to the large extension of the model and the wide range of analysed factors, it will be adapted to the case study according to the local context and the available scientific information through the analysis of climate trends, focusing on the impacts on land uses.

In the lack of local climate scenarios, a set of variables related to the urban issue will be extracted from the analysis of regional projections developed by the IPCC (Intergovernmental Panel on Climate Change, Magrin et al., 2007) and local climate trends based on scientific evidence. The linkages between climate variables and socioeconomic context will be analysed through the identification of spatial implications putting special emphasis on their impact on residential land use typologies. Different types of residential developments suffer from dissimilar effects according to location, services, socioeconomic context and quality of the construction and infrastructure. This document will present the spatial effects of changes on each one of the studied settlements providing information which can contribute to policymakers and other stakeholders on the identification of the vulnerabilities of the area and the generation of adaptation responses.

\section{Section III: Spatial Implications of Climate Variables Related to Urban Development on the Lower Parana Delta}

\section{General Climate Trends for the Area}

The hydrology of the area mainly depends on the discharges of large rivers (such as Parana and Uruguay), precipitations, tides and South Eastern winds coming from the Atlantic Ocean. In consequence, the climate variables that mostly affect the area are related to changes in temperatures, precipitations, winds and sea level rise. Some climatic projections for the area are:

- A possible temperature raise from $0.4^{\circ} \mathrm{C}$ to $1.8^{\circ} \mathrm{C}$ in the next ten years, and up to $7.5^{\circ} \mathrm{C}$ in the next eighty years (Magrin et al., 2007-IPCC-).

- An increase of precipitation. In La Plata Basin, rainfall increased 16\% comparing the periods of 1951-1970 and 1980-1999 (Barros and Bejaran, 2005).

- An increase of river discharge. From every one percent change in precipitation there is a two percent change in river streamflow (Berbery et al., 2006).

- Relevant changes in evaporation rates, which must be balanced with precipitation level to pre-empt floods and guarantee aquifer refills (Barros et al., 2006).

- Displacement of isohyets towards the West (Barros et al., 2006).

- Increase of frequency and intensity of Extreme Hydrological Events (Sudestadas and ENSO-El Niño Southern Oscillation). 
- Increase of the frequency and duration of positive storm surges, causing an increase of water level of the Rio de la Plata (D'Onofrio et al., 2008).

- Decrease of the frequency and duration of negative storm surges, causing decrease in water level of the Rio de la Plata, but an increase in intensity which leads to troubles in water supply (D'Onofrio et al., 2008).

- Increase of water level due to Sea Level Rise (Re, 2005).

Among the above mentioned changes, the variables related with urban development are climate variability and the recurrence of extreme hydrological events. The variability is associated with long periods of droughts and floods, a typical characteristic of wetlands, caused by the rise and fall of the rivers' streamflow and changes in precipitations. The extreme hydrological events are linked to storm surges and strong winds that come from the Atlantic Ocean (called Sudestadas).

\section{River Water Level}

Studies show a great variability of Parana River streamflow, finding relevant differences comparing the periods of 1931-1943, 1944-1970 and 1971-2001 (Figure 3). The first one is considered a period of average discharge, of around $14700 \mathrm{~m}^{3} / \mathrm{sec}$. The second one is considered a dry period because of the decrease in mean streamflow $\left(13900 \mathrm{~m}^{3} / \mathrm{sec}\right)$, and the third period is considered wet because of the increase of medium discharges, which reached $18500 \mathrm{~m}^{3} / \mathrm{sec}$ (Jaime and Menendez, 2002). Although these periods can be distinguished considering mean river streamflow, history shows a great amount of extreme increases and decreases of the river level (Jaime and Menendez, 2002). These events are more often found during the wet period, and recur in cycles of approximately 8 years, together with slight events of high discharge in cycles of 2 to 4 years. The extreme discharge variability causes severe droughts (for instance, the one that took place in 1944, when the river decreased its streamflow to $7703 \mathrm{~m}^{3} / \mathrm{sec}$ ) and large floods (for example, in 1983 and 1992, when the high streamflows reached $53992 \mathrm{~m}^{3} / \mathrm{sec}$ and $54925 \mathrm{~m}^{3} / \mathrm{sec}$ respectively).

Between other factors, changes in river streamflow are related to precipitation and also to the El Niño Southern Oscillation (ENSO). The ENSO is a cycle that takes place in the tropical Eastern Pacific Ocean and is characterized by a change of temperature and pressure of surface waters. With a warming phase called El Niño and a cooling phase called La Niña, ENSO is the main source of variability in South America and in spite of not always being followed by precipitation, it has a great influence on them. In the case study, precipitation variability is mostly influenced by ENSO during the warming phase and also during neutral periods-phases between El Niño and La Niña- (Berbery et al., 2006). Scientific evidence shows a deep connection between the ENSO phenomenon and extreme increases of river discharges, mostly during the period of 1971-2001 (Jaime and Menendez, 2002). There, we can find a relation between the highest level of ENSO and the highest discharge level, with a retard of 3 to 5 months. Strong South-Eastern winds (Sudestadas) also cause extreme floods as a consequence of the increase of Rio de la Plata's level. This phenomenon affects low areas of Buenos Aires and the coasts of Parana Delta, blocking the natural drainage of the waters, streams and canals (Coronel and Menendez, 2006). 


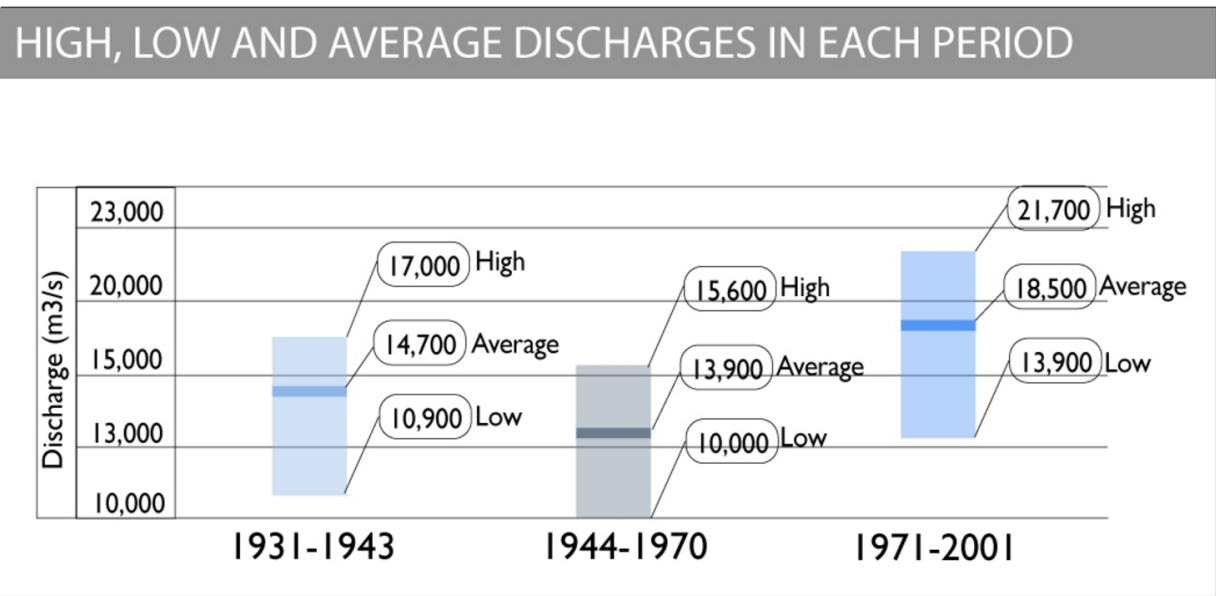

Figure 3: Table of River Discharge

Extreme events of high streamflow are also associated with precipitation levels. The values of mean monthly streamflow rise according to the periods of higher precipitation, often recurring in March and October. Although variability is a natural phenomenon typical of wetlands, it exacerbates due to climate change. Productive activities and urban growth must consider this reality to prevent socioeconomic and ecological damage. For instance, during flooding periods, if land uses such as stockbreeding or agriculture do not adapt to hydrological changes, important economic losses take place. On the other hand, if during a dry period farmers burnt out the pastures as they usually do for preparing the surface for future better crops, they can cause big fires. In fact, during the drought of 2008, the fires expanded, burning out $12 \%$ of the delta surface (Kandus, 2009). In addition to the damage that variability causes on productive lands, it jeopardizes residential lands too, causing different impacts according to the typology of the settlements, their location and socioeconomic situation.

\section{Municipality of Tigre Socioeconomic Context and Urban Patterns}

The Municipality of Tigre has a surface of $360 \mathrm{~km}^{2}$ constituted of $60 \%$ of islands and $40 \%$ of continental lands (Figure 4). The population has increased $44 \%$ in the last 20 years, being mostly located in the urban areas of the continental part. According to the National Census of 2001 (Indec, 2001), 18\% of Tigre's population is under the poverty level. Nevertheless, important real estate developments have occurred since 1990, changing the urban trends of the area (Barros et al., 2006). 


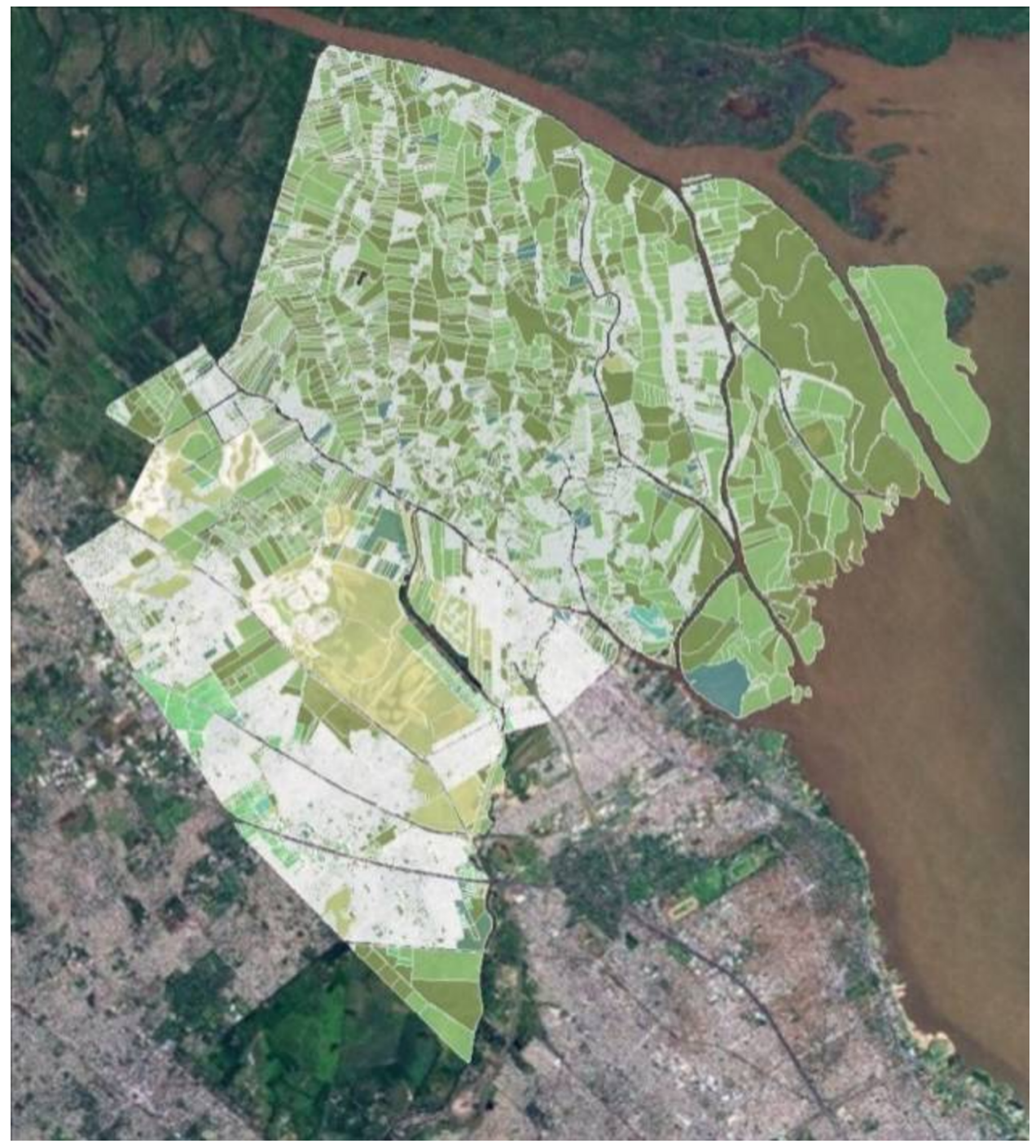

Figure 4: Map of Municipality of Tigre

During that decade, economic liberalization encouraged the expansion of Buenos Aires Metropolitan Area, establishing a complex network of new centralities linked by highways. The urban sprawl grew considerably in what Ciccolella (2002) calls a "Transition of the Urbanization Process" (TPU), which generated new territorial formations as a result of the alteration of the spatial and temporal conditions of production, circulation and consumes. The political and economic context encouraged private developments of neighbourhoods for medium and high social classes, most of them located in the Northern area of Buenos Aires province, even reaching the Parana Delta coastline. The scenario was characterized by a deep Reform of the Estate including the reformulation of urban laws, the construction of transport infrastructure (highways), the decrease of the inflation rate, the increase of Ex- 
ternal Direct Inversions due to the decrease of the international rates of interest, and the retirement of the Estate as a coordinator actor (Ciccolella, 2002). Without any obstacle, private brokers appropriated lands near the River, especially on the lower Delta. The islands of the medium and upper area lost their popularity, a lot of people moved to urban areas with better infrastructure and the population that remained on the islands ended up immersed in poverty. In the Metropolitan Area, the number of private urbanizations or gated communities increased from 100 to 350 during the period of 1995-2000 and nowadays there are more than 400 . According to Ciccolella (2002), the total surface occupied by gated communities is $500 \mathrm{~km}^{2}$ (larger than Buenos Aires city). In Tigre, between 1991 and 2001, the surface occupied by private urbanizations grew around 20 times, from 166 ha to 3313 ha (Ríos, 2005). While high class stakeholders were shaping a new landscape, during the period of 2001-2006, 60\% of the new inhabitants located on informal precarious settlements called "villas" and "asentamientos", forced by the economic crisis (Cravino et al., 2009). The resulting landscape was a polarised scenario full of social inequities: luxurious gated communities and informal settlements located on lands sensitive to flooding.

Private luxury urbanism is typified by the application of foreign urban designs without considering the characteristics of the local context (Daniele et al., 2005). The techniques applied for the development of these residential patterns are the changing of the existing topography through the movement of soil, the transformation of natural water courses, the creation of artificial lagoons and canals and the construction of polders to reach a secure height above sea level, considered by some developers as 4.4 meters (Daniele, 2005). The practice of land infill for the construction of disperse neighbourhoods leaves interstitial spaces under the security levels, increasing the possibility of flooding, apart from causing important environmental harm which includes the loss of the buffer capacity of the area to absorb changes of water level during Sudestadas.

The phenomenon of private urbanizations was economically successful on the continental area and now it is expanding to the islands, which are the most vulnerable lands not only because of the flooding risks but also because of their low resistance. New developments change the islands' topography creating internal lagoons and beaches and even increasing the land level up to $5 \mathrm{~m}$. The developments provide the same services of a continental neighbourhood including electricity, drinking water and sewage treatment. At the present, these developments occupy around 450 ha, which represents $2 \%$ of Tigre's islands (Fajre, 2011), but as they are at their height, it is expected to grow in the near future. In other words, the scenario of residential patterns is complex and diverse, and the changes had been so rapid that the legislation could not adjust to the new requirements. It is important to consider the changing context and the climatic effects on the legislation in order to prevent future disasters and reach to a sustainable use of the lands respecting the ecological and cultural characteristics of the area, which are a key for economic development.

\section{Identification of Residential Pattern Typologies}

Public urbanization; city core: the city core follows the Spanish traditional regular design of orthogonal blocks of around 1 ha. As the territory is not uniformly crossed by water canals, the blocks do not follow a strict regular grid, as many other cities of the country do. The blocks are divided into plots of similar dimensions, and the average of constructed surface is around $140 \mathrm{~m}^{2}$ per plot. According to the legislation (Ordenanza 1894) the urban areas 
is divided into "Semi-urbanized" and "Urbanized" areas, allowing mixed uses such as residential, commercial and industrial. The average permitted densities are 130 inhabitants/ha for the Semi-urbanized area and 1000 inhabitants/ha for the Urbanized one. The highest allowed density is 2000 inhabitants/has for the case of commercial and residential towers. According to the National Census (INDEC, 2001), there is a high coverage of services such as natural gas (72\%), electricity (97\%), public lighting (92\%) and waste collection (96\%), although there is a lower coverage of drinking water $(65 \%)$ and sewage $(15 \%)$.

Private urbanization; gated communities: the legislation considers these private developments as country clubs (clubes de campo) and they are included into the category of "Rural". The design of these neighbourhoods depends on each real estate developer, which establishes internal construction codes. The allowed density is around 30 inhabitants/ha. The provision of services is given by the municipality government, and the deficit of drinkable water is compensated through private treatment systems provided by each development. A few urbanizations have water treatment plants.

Private urbanization; mega-developments: this pattern is ruled under the same conditions of the previous neighbourhoods, but they have a different scale. The emblematic example is "Nordelta", a 160 ha-urban development composed of 19 neighbourhoods, which also has services such as schools, health centre, university, commercial centres, and other equipments.

Illegal settlements: they are called illegal or informal because the inhabitants of these neighbourhoods do not have the formal domain of the lands they occupy. There are two kinds of illegal urbanization: "villas de emergencia" (emergency villas) and "informal settlements". The first type is the spontaneous occupation of private or public lands by one or more families. They are not well organized so the result is an irregular pattern of precarious houses which grow without planning, as new families enter the villa. On the contrary, the second type is an organized occupation of public or private lands following patterns and dimensions similar to the regular city. Most of the cases have the technical support of NGOs and in the municipality of Tigre, they were born between 1965 and 1995. Due to the lack of services such as drinkable water and sewage, and an unplanned location in the floodplains, they present a high vulnerability to natural disasters. 


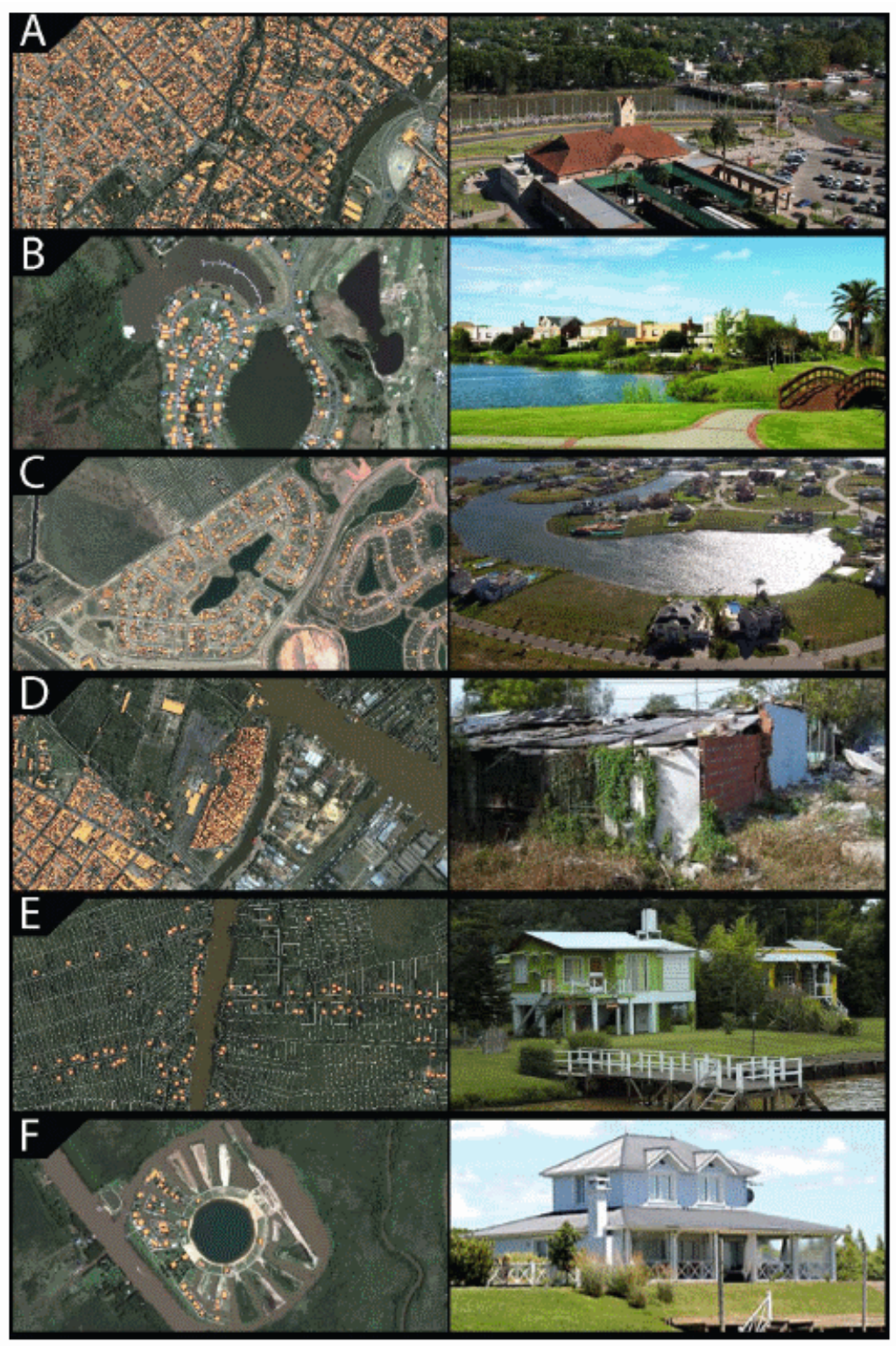

Figure 4: City core; B) Gated Communities; C) Mega-developments; D) Illegal Settlements; E) Disperse Housing on the Islands; F) Private Developments on the Islands

Dispersed housing on the islands: according to the National Census (INDEC, 2001) the islands of Tigre have 5034 permanent inhabitants. Due to the decrease of the original activities (agriculture and traditional crafts), and the increase of tourism and weekend housing, the permanent population is decreasing while the temporary population is increasing, reaching 11900 inhabitants each weekend. The original typology of island housing was characterized by plots up to $2000 \mathrm{~m}^{2}$ with a small pile-dwelling construction, but this is changing 
adapting to the new activities. The coverage of services is relatively acceptable in terms of electricity and waste collection, but there is not drinkable water provision to all the houses. On the contrary, the municipality provides drinking water only to schools, public buildings health centres or touristic developments. Most of the inhabitants of the islands treat the water extracted from the natural courses through domestic techniques, while the poorest sectors do not treat it at all. There is no sewerage system so people use septic tanks and then dump the waste directly to the water courses.

Private urban developments on the islands: these developments are focused on nautical and tourist activities, and in general offer plots of around 600 up to $2500 \mathrm{~m}^{2}$ each. They are constructed over the safe height and provide a wide range of services. The housing typology emulates the type used in continental gated communities. They have a good coverage of services (electricity, public lighting, waste collection) but they have to treat the water to make it drinkable by using their own plants. A few of these developments have sewage treatment plants.

\section{Discussion. Linkages between Climate Change and Urban Residential Patterns}

Extreme hydrological events and variability are likely to be among the most serious direct impacts of climate change in the area because of its coastal location. The linkage between the climate scenario and the changes in urban development typologies is the key to develop sustainable policies to face the uncertainties of the near future. It is possible to establish relation chains to define the direct environmental risk and its spatial implication for each case as a way to identify the most important necessities. Some of the possible chains are:

Periods of drought $>$ decrease of water level $>$ population increase + waste increase $>$ lack of sewage treatment plants $>$ decrease of water quality $>$ water not fit for consumption $>$ need for private economic inversion to treat the water. (Dispersed housing on the islands)

Periods of drought $>$ decrease of water level $>$ population increase + waste increase $>$ lack of sewage treatment plants $>$ decrease of water quality $>$ water not fit for consumption $>$ free consumption of the resource $>$ poor health and illness. (Illegal neighbourhoods)

Precipitation increase + raise of water level $>$ changes in water courses due to infill practices $>$ generation of new interstitial floodplains $>$ extreme hydrological events $>$ flooding. (Dispersed housing on the islands; Illegal neighbourhoods; Public urbanization-city core)

Extreme hydrological events $>$ coastal exposition to Sudestadas $>$ flooding $>$ building and infrastructure damage. (Private urban developments on the islands)

Streamflow variability $>$ increase of water level $>$ climate effects uncertainty $>$ rise of the level of the new urban developments far beyond the average heights $>$ increase of 
differences of heights between original delta islands and new topographies $>$ increase of flooding in surrounding areas $>$ change of biological characteristics. (Dispersed housing on the islands)

Extreme hydrological events $>$ changes in topography $>$ uncertainty of flooding effects and new floodplains location > flooding. (Gated communities; Mega-developments)

Precipitation increase $>$ increase of construction + decrease of absorbing surfaces $>$ loss of buffer condition of the wetland $>$ reduction of natural response to extreme hydrological events $>$ need for resources and more adaptation policies. (Whole district)

The spatial implications for each urban typology include the necessity of the identification of the new floodplains and the definition of safe construction heights, together with an improvement of land use regulations. For the case of new private developments, it is important to emphasise the sustainability of each proposal, not only from the ecological point of view, but also thinking about the surrounding socioeconomic context and the effects of this gated communities in each area. They need to be considered as urban developments and leave behind the categorization of "rural" because of their dissimilar effects on the environment, their intensive demand of services and the population density. High-impact private urbanization on the islands must also be included as a new typology in the legislation and follow a strict control of the environmental and socioeconomic impact. Local inhabitants must be aware of new developments on the area and the changes that they cause. For the case of informal settlements, spatial implications are related to the vulnerable location and the lack of services and its effects on health (Figure 5).

A set of spatial policy responses from the basis of the previous analysis addresses:

- Legislation improvement including the new residential typologies. Establishment of new rules according to each relationship with the socioeconomic context and the future climatic scenarios.

- Research activities that include topographic analysis, identification of floodplains, safe heights, empty plots susceptible to be illegally occupied, etc.

- Regularization of the existing informal settlements though the transference of the domain to the inhabitants, the provision of services and the improvement of the building and urban conditions.

- Increase the coverage of services such as drinking water and sewage.

- Development of local spatial strategies including the regeneration of the degraded areas; the protection of the most vulnerable lands including the newest islands of the delta; the conservation of the cultural identity though the continuity of the practice of original activities and the permanence of the typical inhabitants; the preservation of the wetland and the services that it provides for future generations; the balance between the existing context and the new opportunity areas, etc.

- Design and implementation of adaptation policies concerning agricultural activities and social participation. 


\section{Conclusions}

The territory of Tigre is being rapidly transformed by natural and urban drivers and bears the pressures of the demographic growth of Buenos Aires Metropolitan Area. The coastal condition and the unequal socioeconomic context turn it into a vulnerable place which suffers the deep consequences of climate events. The scheme developed in this document aims to manage the complexity of the linkages between (uncertain) climate events and (rapid) urban changes. Furthermore, it develops a characterization of the different types of residential patterns found in the area, which are not being mentioned or are even considered in the current land use legislation. New rules must be designed to find a balance between changes.

Through the identification of the spatial implications of climate related variables it is possible to broad the chains of linkages to other issues in order to find new conflictive points and reach to successful policies. These kinds of studies are possible to be applied not only on the decision making level (top-down) but also to be used in programs based on community participation (bottom up). In this case, spatial implications could be analysed from the inhabitants' perspective in order to build new linkages according to each group's interests. Although this study has a limited scope, it can be taken forward (from a local or a regional perspective) to help not only policymakers but also other stakeholders to adapt to the changing context and the uncertainty of climate variations. 
THE INTERNATIONAL JOURNAL OF CLIMATE CHANGE: IMPACTS AND RESPONSES

\section{Summary}

\begin{tabular}{|c|c|c|c|}
\hline Typology & Location & Spatial implication & Policy response \\
\hline $\begin{array}{l}\text { Public urbanization; } \\
\text { city core }\end{array}$ & & $\begin{array}{l}\text { Identification of } \\
\text { floodplains. } \\
\text { Improvement of } \\
\text { infrastructure. }\end{array}$ & $\begin{array}{l}\text { Identification of } \\
\text { floodplains. } \\
\text { Improvement of } \\
\text { infrastructure. } \\
\text { Regeneration of } \\
\text { degraded areas. }\end{array}$ \\
\hline Private developments & & $\begin{array}{l}\text { Infill practices. } \\
\text { Increase of demand of } \\
\text { infrastructures. } \\
\text { Social polarization. } \\
\text { Topography changes. }\end{array}$ & $\begin{array}{l}\text { Inclussion of new land } \\
\text { uses in the legislartion } \\
\text { according to the new } \\
\text { urban trends. } \\
\text { Impact control. } \\
\text { Regulation of infill } \\
\text { practices. }\end{array}$ \\
\hline Mega-developments & & $\begin{array}{l}\text { Infill practices. } \\
\text { Increase of demand of } \\
\text { infrastructures. } \\
\text { Social polarization. } \\
\text { Topography changes. } \\
\text { New uses in rural lands. }\end{array}$ & $\begin{array}{l}\text { Improvement of } \\
\text { legislation concerning } \\
\text { climate adaptation. } \\
\text { Integration policies. } \\
\text { Balance between public } \\
\text { and private interests. }\end{array}$ \\
\hline Informal settlements & & $\begin{array}{l}\text { Lack of infrastructure. } \\
\text { Health problems. } \\
\text { Vulnerable location. } \\
\text { Idcntification of } \\
\text { empty plots susceptible } \\
\text { to be illegally occupied. }\end{array}$ & $\begin{array}{l}\text { Regularization of the } \\
\text { existing informal } \\
\text { settlements. } \\
\text { Infrastructure } \\
\text { improvement. } \\
\text { Social inclussion of the } \\
\text { inhabitants. }\end{array}$ \\
\hline $\begin{array}{l}\text { Disperse housing on } \\
\text { the islands }\end{array}$ & & $\begin{array}{l}\text { Soil crosion. } \\
\text { Activities change. } \\
\text { Flood risk assessment. } \\
\text { Lack of infrastructure. } \\
\text { Relation with new } \\
\text { developments and uses. }\end{array}$ & $\begin{array}{l}\text { Adaptation policies } \\
\text { including inhabitants } \\
\text { and typical activities. } \\
\text { Restoration. } \\
\text { Conservation of cultural } \\
\text { identity. }\end{array}$ \\
\hline $\begin{array}{l}\text { Private developments } \\
\text { on the islands }\end{array}$ & & $\begin{array}{l}\text { Soil erosion. } \\
\text { Flood risk assessment. } \\
\text { Balance between } \\
\text { existing context and } \\
\text { opportunity areas. }\end{array}$ & $\begin{array}{l}\text { Wetland conservation. } \\
\text { Protec tion of } \\
\text { vulnerable lands. } \\
\text { Impact control. } \\
\text { Lcgislation improve- } \\
\text { ment. }\end{array}$ \\
\hline
\end{tabular}

Figure 5: Summary of Spatial Implication in Each Type of Urbanization 


\section{References}

Barros, V., Bejarán, R., 2005. “Adaptación al cambio climático en Argentina. Dónde estamos?” CIMACONICET, Buenos Aires.

Barros, V., Clarke, R., Silva Dias, P.S., 2006. Climate Change in La Plata Basin. Trends in the Hydrological cycle of the Plata basin. IAI-CONICET, Buenos Aires.

Barros, V., Menéndez, A., Natenzon, C., Kokot, R., Codignotto, J., Re, M., Bronstein, P., Camilloni, I., Ludueña, S., González, S., Ríos, D., 2006. "Vulnerability to floods in the metropolitan region of Buenos Aires under future climate change.” AIACC Working Paper No. 26. Washington.

Berbery, E., Doyle, M., Barros, V., 2006. "Regional Precipitation Trends.” in: Barros, V., Clarke, R., Silva Dias, P.S. Climate Change in La Plata Basin. Trends in the Hydrological cycle of the Plata basin, IAI-CONICET, Buenos Aires, pp. 61-73.

Bennet, R., Pettit, C., Auranbout, J., Sheth, F., Senot, h., Soste, L., Sposito, V., 2009. "Visualizing climate change impact with ubiquitous spatial technologies. Joint International Conference on Theory, Data Handling and Modelling." In GeoSpatial Information Science, Hong Kong $26-28^{\text {th }}$ May.

Centre for Urban \& Regional Ecology, 2003. "Spatial implications of climate change for the North West." Main Report. School of Planning \& Landscape, University of Manchester, Manchester.

Ciccollela, 2002. P., 2002. "La metrópolis postsocial: Buenos Aires, ciudad-rehén de la economía global." in: Actas del Seminario Internacional "El desafío de las áreas metropolitanas en un mundo globalizado. Una mirada a Europa y América Latina", Barcelona.

Cravino, M., Del Río, J., Duarte, J., 2009. "Magnitud y crecimiento de las villas y asentamientos en el Área Metropolitana de Buenos Aires en los últimos 25 años."

Coronel, G., Menendez, A., 2006. "Physiography and Hydrology.” In Barros, V., Clarke, R., Silva Dias, P.S., Climate Change in La Plata Basin. Trends in the Hydrological cycle of the Plata basin, IAI-CONICET, Buenos Aires, pp. 44-60.

Daniele, C., Ríos, D., De Paula, M., Frassetto, A., 2005. "Impacto y riesgo de la expansión urbana sobre los valles de inundación en la Región Metropolitana de Buenos Aires.” pp. 457-461.

D'Onofrio, E., Fiore, M. Pousa, J., 2008. "Changes in the Regime of Storm Surges at Buenos Aires, Argentina." Journal of Coastal Research, Vol.24, No. 1A. pp. 260-265.

Fajre \& Asociados, 2001. "Plan de manejo de las islas del Delta." Municipalidad de Tigre, Fundación Metropolitana, Buenos Aires.

Holl, B. and Mauser, W., on behalf of the German National Committee on Global Change Research (NKGCF), 2008. "Global Change Research in Germany 2008." Munich.

INDEC, (Instituto Nacional de Estadística y Censos de la República Argentina), 2001. "Censo Nacional de Población,” Hogares y Viviendas 2001. http://www.indec.mecon.ar

INDEC, (Instituto Nacional de Estadística y Censos de la República Argentina), 2010. "Censo Nacional de Población," Hogares y Viviendas 2010. Preliminar results. http://www.indec.mecon.ar

Jaime, P. and Menendez, A., 2002. "Análisis del régimen hidrológico de los ríos Paraná y Uruguay." Informe LHA 05-216-02, Proyecto LHA 216, Instituto Nacional de Agua (INA), Buenos Aires.

Kandus, P., 2009. "Incendios de 2008 en el Delta del Río Paraná, Argentina. Análisis ecológico sobre el sector de islas frente a las localidades de Zárate, Baradero y San Pedro.” Informe Técnico, Universidad General San Martín, Buenos Aires.

London School of Economics and Political Science, 2010. "Urban Age South America." Cities Programme organized by the London School of Economics and Political Science and the Alfred Herrhausen Society, the International Forum of Deutsche Bank. London. 
Magrin, G., Gay García, C., Cruz Choque, D., Gimenez, J.C., Moreno, A.R., Nagy, G.J., Nobre, C., Villamizar, A., 2007. "Latin America. Climate Change 2007: Impacts, Adaptation and Vulnerability.” In: Parry, M.L., Canziani, O.F., Palutikof, J.P., van der Linden, P.J., Hanson, C.E. (Eds.), Contribution of Working Group II to the Fourth Assessment Report of the Intergovernmental Panel on Climate Change, Cambridge University Press, Cambridge, pp. 581-615.

Pearce D., Cline, W., Achanta, a., Frankenhauser, S., Pachauri, R., Tol, R., Vellinga, P., 1996. “The social costs of climate change: greenhouse damage and the benefits of control." In: Bruce, J. Lee, H, Haites, E., (Eds.), Climate Change 1995: Economic and Social Dimension of Climate Change, Cambridge University Press, Cambridge.

Pittau, M., Sarubbi, A., Menéndez, A., 2004. “Análisis del avance del frente y el incremento areal del Delta del Río Paraná.” Instituto Nacional del Agua (INA), Buenos Aires.

Re, 2005. "Impacto del Cambio Climático Global en las costas del Rio de la Plata." Universidad de Buenos Aires, Buenos Aires.

Ríos, D., 2005. "Planificación urbana privada y desastres de inundación. Las urbanizaciones cerradas polderizadas en el municipio de Tigre, provincia de Buenos Aires, Argentina.” Revista EST Economía, Sociedad y Territorio, Vol. V., no. 17.

Sheppard, S. 2005. "Landscape visualisation and climate change: the potential for influencing perceptions and behaviour." Environmental Science and Policy, 8 (637-654).

\section{About the Author}

MSc Veronica M.E. Zagare

Verónica Zagare is an Architect. She graduated cum laude from the University of Belgrano, in Buenos Aires, Argentina in 2000. She has recently finished her Masters in Urban Economics at the Di Tella University, in Buenos Aires (scholarship winner) and also attended a Specialization of Histories of Architecture and Urbanism at the University of Buenos Aires (scholarship winner). She is conducting her $\mathrm{PhD}$ at the Department of Urbanism, at the Architecture Faculty of Delft University of Technology (the Netherlands). Her research addresses the development of planning instruments to deal with natural territories, growing urban processes, socio-economic events and climate change. She focuses her investigation on coastal areas, studying the case of the Paraná Delta (Argentina). She is currently a researcher at the Instituto Superior de Urbanismo of the University of Buenos Aires. 


\section{JOURNAL OF GLIMATE CHAHEEE}

A) $C O M M O N$

G G R U N D

\section{Editors}

Amareswar Galla, International Institute for the Inclusive Museum

Bill Cope, University of Illinois, Urbana-Champaign, USA

\section{Editorial Advisory Board}

Alison Anderson, Head of Sociology/Social Policy Study Group, University of Plymouth, Plymouth, UK

Viraal Balsari, Vice President, ABN Amro Bank, Mumbai, India

Erach Bharucha, Bharati Vidyapeeth Univeristy, Pune, India

Tapan Chakrabarti, National Environmental Engineering Research Institute (NEERI), Nagpur, India

Amareswar Galla, Executive Director, International Institute for the Inclusive Museum, Paris, Chicago, Sydney and Hyderabad

Thomas Krafft, Geomed Research Corporation, Bad Honnef, Germany

Shamita Kumar, Bharati Vidyapeeth Univeristy, Pune, India

R. Mehta, Ministry of Environment and Forests, Government of India, New Delhi, India Amy Snover, Climate Impacts Group, University of Washington, Seattle, USA

Kranti Yardi, Bharati Vidyapeeth Univeristy, Pune, India

Zhihua Zhang, Research Professor \& Senior Scientist, College of Global Change \& Earth System Sciences \& Deputy Director of Polar Climate \& Environment Key Laboratory, Beijing Normal University, China

Please visit the Journal website at http://www.Climate-Journal.com for further information about the Journal or to subscribe. 


\section{The Climate Change Community}

This knowledge community is brought together by a common concern for scientific policy and strategic perspective in climate change. The community interacts through an innovative, annual face-to-face conference, as well as year-round virtual relationships in a weblog, peer reviewed journal and book series - exploring the affordances of the new digital media. Members of this knowledge community include academics, educators, administrators, policy makers, consultants, researchers and research students.

\section{Conference}

Members of the Climate Change Community meet annually at the International Conference on Climate Change: Impacts and Responses, held annually in different locations around the world. The Conference was held at the Bharati Vidyapeeth Institute of Environment Education and Research, Pune, India in 2009; at the University of Queensland, Brisbane, Australia in 2010; and in Rio De Janeiro, Brazil in 2011. In 2012, the Conference will be held at the University of Washington, Seattle, USA.

This Conference examines evidence of climate change, its natural and human causes, its ecosystemic impacts and its human impacts. The Conference also addresses technological, social, ethical and political responses to climate change.

Our community members and first time attendees come from all corners of the globe. The Conference is a site of critical reflection, both by leaders in the field and emerging scholars. Those unable to attend the Conference may opt for virtual participation in which community members can submit a video and/or slide presentation with voiceover, or simply submit a paper for peer review and possible publication in the Journal.

Online presentations can be viewed on YouTube.

\section{Publishing}

The Climate Change Community enables members to publish through three mediums. First, by participating in the Climate Change Conference, community members can enter a world of journal publication unlike the traditional academic publishing forums - a result of the responsive, non-hierarchical and constructive nature of the peer review process. The International Journal of Climate Change: Impacts and Responses provides a framework for double-blind peer review, enabling authors to publish into an academic journal of the highest standard.

The second publication medium is through the book series On Climate, publishing cutting edge books in print and electronic formats. Publication proposals and manuscript submissions are welcome.

Our third major publishing medium is our news blog, constantly publishing short news updates from the Climate Change community, as well as major developments in scientific policy and strategic perspectives in climate change. You can also join this conversation at Facebook and Twitter or subscribe to our email Newsletter. 


\section{Common Ground Publishing Journals}

\begin{tabular}{|c|c|}
\hline $\begin{array}{l}\text { AGING } \\
\text { Aging and Society: An Interdisciplinary Journal } \\
\text { Website: http://AgingAndSociety.com/journal/ }\end{array}$ & $\begin{array}{c}\text { ARTS } \\
\text { The International Journal of the Arts in Society. } \\
\text { Website: www.Arts-Journal.com }\end{array}$ \\
\hline $\begin{array}{c}\text { BOOK } \\
\text { The International Journal of the Book } \\
\text { Website: www.Book-Journal.com }\end{array}$ & $\begin{array}{c}\text { CLIMATE CHANGE } \\
\text { The International Journal of Climate Change: } \\
\text { Impacts and Responses } \\
\text { Website: www.Climate-Journal.com }\end{array}$ \\
\hline $\begin{array}{c}\text { CONSTRUCTED ENVIRONMENT } \\
\text { The International Journal of the } \\
\text { Constructed Environment } \\
\text { Website: www.ConstructedEnvironment.com/journal }\end{array}$ & $\begin{array}{c}\text { DESIGN } \\
\text { Design Principles and Practices: } \\
\text { An International Journal } \\
\text { Website: www.Design-Journal.com }\end{array}$ \\
\hline $\begin{array}{c}\text { DIVERSITY } \\
\text { The International Journal of Diversity in } \\
\text { Organizations, Communities and Nations } \\
\text { Website: www.Diversity-Journal.com }\end{array}$ & $\begin{array}{l}\text { FOOD } \\
\text { Food Studies: An Interdisciplinary Journal } \\
\text { Website: http://Food-Studies.com/journal/ }\end{array}$ \\
\hline $\begin{array}{c}\text { GLOBAL STUDIES } \\
\text { The Global Studies Journal } \\
\text { Website: www.GlobalStudiesJournal.com }\end{array}$ & $\begin{array}{c}\text { HEALTH } \\
\text { The International Journal of Health, } \\
\text { Wellness and Society } \\
\text { Website: www.HealthandSociety.com/journal }\end{array}$ \\
\hline $\begin{array}{c}\text { HUMANITIES } \\
\text { The International Journal of the Humanities } \\
\text { Website: www.Humanities-Journal.com }\end{array}$ & $\begin{array}{c}\text { IMAGE } \\
\text { The International Journal of the Image } \\
\text { Website: www.Onthelmage.com/journal }\end{array}$ \\
\hline $\begin{array}{l}\text { LEARNING } \\
\text { The International Journal of Learning. } \\
\text { Website: www.Learning-Journal.com }\end{array}$ & $\begin{array}{c}\text { MANAGEMENT } \\
\text { The International Journal of Knowledge, } \\
\text { Culture and Change Management. } \\
\text { Website: www.Management-Journal.com }\end{array}$ \\
\hline $\begin{array}{c}\text { MUSEUM } \\
\text { The International Journal of the Inclusive Museum } \\
\text { Website: www.Museum-Journal.com }\end{array}$ & $\begin{array}{c}\text { RELIGION AND SPIRITUALITY } \\
\text { The International Journal of Religion and } \\
\text { Spirituality in Society } \\
\text { Website: www.Religion-Journal.com }\end{array}$ \\
\hline $\begin{array}{c}\text { SCIENCE IN SOCIETY } \\
\text { The International Journal of Science in Society } \\
\text { Website: www.ScienceinSocietyJournal.com }\end{array}$ & $\begin{array}{c}\text { SOCIAL SCIENCES } \\
\text { The International Journal of Interdisciplinary } \\
\text { Social Sciences } \\
\text { Website: www.SocialSciences-Journal.com }\end{array}$ \\
\hline $\begin{array}{c}\text { SPACES AND FLOWS } \\
\text { Spaces and Flows: An International Journal of } \\
\text { Urban and ExtraUrban Studies } \\
\text { Website: www.SpacesJournal.com }\end{array}$ & $\begin{array}{c}\text { SPORT AND SOCIETY } \\
\text { The International Journal of Sport and Society } \\
\text { Website: www.sportandsociety.com/journal }\end{array}$ \\
\hline $\begin{array}{c}\text { SUSTAINABILITY } \\
\text { The International Journal of Environmental, Cultural, } \\
\text { Economic and Social Sustainability } \\
\text { Website: www.Sustainability-Journal.com }\end{array}$ & $\begin{array}{c}\text { TECHNOLOGY } \\
\text { The International Journal of Technology, } \\
\text { Knowledge and Society } \\
\text { Website: www.Technology-Journal.com }\end{array}$ \\
\hline $\begin{array}{c}\text { UBIQUITOUS LEARNING } \\
\text { Ubiquitous Learning: An International Journal } \\
\text { Website: www.ubi-learn.com/journal/ }\end{array}$ & $\begin{array}{l}\text { UNIVERSITIES } \\
\text { Journal of the World Universities Forum } \\
\text { Website: www.Universities-Journal.com }\end{array}$ \\
\hline
\end{tabular}

